\title{
HAK JAMAAH HAJI ATAS HASIL PENGELOLAAN SETORAN AWAL BIAYA PENYELENGGARAAN IBADAH HAJI
}

\author{
Juju Jumena, Ilham Bustomi dan Siti Fatimah \\ Fakultas Syariah dan Ekonomi Islam \\ Institut Agama Islam Negeri Syekh Nurjati Cirebon \\ e-mail: jumena72@yahoo.com,khotibulumam454@yahoo.co.id \\ dan sitifatimah.sf435@gmail.com
}

\begin{abstract}
Cooperative as a manifestation of the economic development of democracy. This happens when the cooperative is well managed, The existence of cooperatives in the District of Gunungjati has not described the cooperative as a form of economic development populist.This study aims to answer from the questions that become the formulation of the problem, how SWOT Cooperative as a Form of Community Economic Development in the District of Gunungjati? This research uses qualitative research,The data collected by interview technique (interview), observation, documentation and then analyzed by descriptive method of analysis.The SWOT analysis results that can be submitted by the authors are the cooperatives in the District of Gunungjati has the power in management,And has a weakness of the level of public confidence,Besides the cooperative opportunities for cooperation with financial institutions are very open, On the other hand the threat is the ease of provision of borrowers of informants (middlemen) who are still very difficult to overcome.
\end{abstract}

Keywords: Cooperative, SWOT Analysis, and Community Economic.

\begin{abstract}
Abstrak
Koperasi sebagai wujud dari pembangunan ekonomi kerakyatan. Hal ini terjadi apabila koperasi dikelola dengan baik, keberadaan koperasi di Kecamatan Gunungjati belum mendiskripsikan koperasi sebagai wujud pembangunan ekonomi kerakyatan. Penelitian ini bertujuan untuk menjawab dari pertanyaan-pertanyaan yang menjadi rumusan masalah, bagaimana SWOT Koperasi Sebagai Wujud Pembangunan Ekonomi Kerakyatan di Wilayah Kecamatan Gunungjati? Penelitian ini menggunakan penelitian kualitatif, data yang dikumpulkan dengan teknik interview (wawancara), observasi, dokumentasi kemudian dianalisis dengan metode deskriptif analisis. Adapun hasil analisis SWOT yang dapat disimpulkan oleh penulis adalah koperasi-koperasi di Kecamatan Gunungjati memiliki kekuatan di manajemen, dan mempunyai kelemahan dari tingkat kepercayaan masyarakat, selain itu peluang koperasi untuk kerjasama dengan lembaga keuangan sangat terbuka, disisi lain ancamannya adalah kemudahan penyediaan pinjam informan (tengkulak) yang masih sangat sulit diatasi.
\end{abstract}

Kata Kunci: Koperasi, Analisis SWOT, dan Ekonomi Kerakyatan. 


\section{PENDAHULUAN}

Ibadah haji merupakan rukun Islam kelima setelah syahadat, shalat, zakat, dan puasa yang wajib dilaksanakan bagi setiap muslim yang telah memenuhi syarat baik secara fisik, materi, maupun mental. Karena ibadah haji merupakan kewajiban bagi setiap muslim, maka ibadah ini telah diterangkan dan ditetapkan secara jelas dalam al-Qur'an, al-Sunnah dan Ijma. Dan meskipun ibadah haji membutuhkan biaya yang cukup besar, ibadah haji tetap menjadi impian besar bagi sebagian umat Islam. Hal tersebut menunjukan betapa istimewanya ibadah haji. ${ }^{1}$ Untuk melaksanakan ibadah haji diperlukan banyak persiapan yang melibatkan berbagai sektor pendukung. Oleh sebab itu dalam mengkaji tentang haji tidak hanya dilihat dari sisi ritual ibadah saja, namun juga dapat dilihat atau dikaji dari sisi muamalahnya.

Dengan diperlukannya persiapan yang melibatkan banyak sektor pendukung, maka dalam pelaksanaan ibadah haji timbullah akad antara calon jamaah haji dengan pihakpihak yang terkait. Menurut ulama fiqh, kata akad didefinisikan sebagai hubungan antara ijab dan kabul sesuai dengan kehendak syariat yang menetapkan adanya pengaruh (akibat) hukum dalam objek perikatan. Dan menurut Kompilasi Hukum Ekonomi Syariah, yang dimaksud dengan akad adalah kesepakatan dalam suatu pejanjian antara dua pihak atau lebih untuk melakukan dan atau tidak melakukan pebuatan hukum tertentu. $^{2}$ Dari adanya akad maka akan timbul pengaruh (akibat) hukum dalam objek akad atau hak dan kewajiban bagi setiap pihak yang berakad. ${ }^{3}$

\footnotetext{
${ }^{1}$ Khalifi Elyas Bahar, Do'a dan Amalan agar Mendapat Panggilan Ziarah Haji dan Umrah (Yogyakarta: DIVA Press, 2013), 14-15.

${ }^{2}$ Mardani, Figh Ekonomi Syariah (Jakarta: Kencana, 2012), 71.

${ }^{3}$ Ismail Nawawi, Fikih Muamalah Klasik dan Kontemporer Hukum Perjanjian, Ekonomi, Bisnis, dan Sosial (Bogor: Ghalia Indonesia, 2012), 43.
}

Porsi dana haji di Indonesia begitu besar, di Kota Cirebon saja pendaftar haji hingga 21 Juni 2018 tercatat sebanyak 5188 orang, dengan setoran awal masing-masing sebesar 25 juta rupiah. $^{4}$ Jelas dalam pengelolaan dana setoran awal yang terkumpul tersebut memiliki potensi ekonomi yang cukup besar, seperti yang termaktub dalam Undang-Undang No 34 Tahun 2014 tentang Pengelolaan Keuangan Haji yang menjelaskan bahwa akumulasi dana haji berpotensi ditingkatkan nilai manfaatnya guna mendukung penyelenggaraan ibadah haji yang lebih berkualitas melalui pengelolaan keuangan haji yang efektif, efisien, transparan serta akuntabel. Untuk melakukan pengelolaan keuangan haji, undang-undang tersebut membentuk Badan Pengelola Keuangan Haji (BPKH) sebagai badan hukum publik yang bersifat mandiri dan bertanggung jawab kepada Presiden melalui Menteri. Dari besarnya potensi ekonomi pengelolaan keuangan haji, mengakibatkan adanya perdebatan di masyarakat terkait berhak atau tidaknya jamaah haji atas hasil pengelolaan keuangan haji tersebut. Oleh karena itu, maka penulis merasa perlu mengkaji lebih dalam mengenai 1) Apakah jenis akad yang digunakan oleh calon jamaah haji ketika menyetorkan dana awal Biaya Penyelenggaraan Ibadah Haji (BPIH)? 2) Apakah jamaah berhak atas hasil pengelolaan dana setoran awal BPIH?

\section{LITERATURE REVIEW}

Peneletian tentang pengelolaan dana haji bukanlah sesuatu yang baru. Meskipun demikian, nampaknya belum ditemukan penelitian yang secara spesifik mengkaji terkait hak jamaah haji atas hasil pengelolaan dana haji. Berikut beberapa karya yang terdokumentasikan terkait

\footnotetext{
${ }^{4}$ https://jabar.kemeneag.go.id/dberita506069-pendaftar-ibadah-haji-kota-cirebonmembludak-kakankemenag-perkenalkan-10-inovasipenyelenggaraan-haji. Diakses pada tanggal 4 Juli 2018.
} 
permasalahan yang akan penulis kaji, yaitu pertama, penelitian Ayu Azhara dan Jelita ${ }^{5}$ yang berjudul "Manajemen Dana Tabungan Haji Ditinjau Dari Perspsektif Ekonomi Islam Pada PT. Bank BNI Syariah dan PT. Bank Syariah Mandiri Palangkaraya". Menjelaskan sistem yang digunakan pada PT. Bank Syariah Mandiri dalam pengelolaan sumber dana bank, yaitu sistem pooling. Metode ini merupakan sebuah mekanisme hasil dari implementasi tatanan kinerja kedua perbankan dalam melakukan pengelolaan dana yang dihimpun dari masyarakat serta sebagai bentuk pembuktian dalam pelaksanaan tanggung jawab serta refleksi atas berjalan baik atau tidaknya prinsip-prinsip syariah dalam kinerja bank sebagai sebuah lembaga intermediasi. Dalam tulisannya tersebut, baik produk maupun pengelolaan dana yang ada masih harus menyesuaikan dengan prinsip-prinsip ekonomi syariah dengan jalan menggali, memahami serta mendalami tiap-tiap bagian dari ruang lingkup ekonomi syariah.

Kedua, penelitian Nurul Izzati $^{6}$ dalam tesisnya yang berjudul "Kontruksi Model Pengelolaan Keuangan Haji Pada Bank Syariah di Indonesia”. Kontruksi pengelolaan keuangan haji dapat dilakukan melalui kontrak antara jamaah haji dan Badan Pengelolaan Keuangan Haji (BPKH) dengan akad wadi'ah yad dhamanah atau dengan penempatan pada dana pihak I bank syariah dengan akad Musyarakah mutanaqishah.

Dan ketiga, oleh Dekky Aditya ${ }^{7}$ dalam skripsinya yang berjudul "Pelaksanaan

${ }^{5}$ Ayu Azhara dan Jelita, "Manajemen Dana Tabungan Haji Ditinjau Dari Perspsektif Ekonomi Islam Pada PT. Bank BNI Syariah dan PT Bank Syariah Mandiri Palangkaraya", Jurnal al-Qard, Vol. 4, No. 2 (Desember, 2017).

${ }^{6}$ Nurul Izzati, "Kontruksi Model Pengelolaan Keuangan Haji Pada Bank Syariah di Indonesia", Tesis (Yogyakarta: Fakultas Ilmu Ekonomi Islam Universitas Islam Negeri Sunan Kalijaga, 2015).

${ }^{7}$ Dekky Aditya K. Putra, "Pelaksanaan Akad Tabungan Haji Pada Bank Riau Kepri Syari’ah
Akad Tabungan Haji Pada Bank Riau Kepri Syari'ah Cabang Pekanbaru". Dalam pelaksanaan akad tabungan haji Pada Bank Riau Kepri Syari'ah Cabang Pekanbaru ada dua macam tabungan haji, yaitu 1) Skim Wadi'ah (bebas) degan tidak menerapkan sistem bagi hasil, dan 2) Skim Mudharabah (terencana) dengna menerapkan sistem bagi hasil. Untuk mempercepat mendapat porsi atau pemberangkatan haji, nasabah dapat melunasi segera sisa pembayaran atau mengajukan dana talangan pada pihak bank untuk membantu pelunasan biaya ibadah haji. Dana talangan tersebut tentunya harus dibayar oleh pihak nasabah dalam jangka waktu tertentu dan pihak bank berhak mendapat keuntungan. Dan dalam pelaksanaan akad terdapat beberapa kendala, diantaranya timbul karena kurangnya informasi yang diberikan oleh masing-masing pihak.

Dari ketiga topik penelitian yang telah dipaparkan di atas, ternyata belum ada tinjauan secara khusus dan komprehensif terkait hak jamaah haji atas hasil pengelolaan setoran awal biaya peyelenggaraan ibadah haji. Dengan adanya penelitian ini diharapkan bisa menjawab perdebatan yang terjadi di masyarakat terkait berhak atau tidaknya jamaah haji atas hasil pengelolaan setoran awal biaya peyelenggaraan ibadah haji. Di sinilah letak perbedaan studi ini dengan studi-studi yang telah dilakukan sebelumnya.

\section{METODE PENELETIAN}

Dalam penelitian ini, jenis penelitian yang dilakukan adalah jenis penelitian Kualitatif, artinya data-data yang dikumpulkan bukan berupa kumpulan angka, melainkan dari wawancara, kegiatan observasi, catatan lapangan, dokumen resmi dan lain-lain. Sehingga yang menjadi tujuan dari penelitian kualitatif ini adalah ingin meggambarkan realita empirik dibalik fenomena secara mendalam. Oleh karena

Cabang Pekanbaru", Skripsi (Padang: Fakultas Hukum Universitas Andalas, 2011). 
itu, penggunaan pendekatan kualitatif dalam penelitian ini adalah dengan mencocokan antara realita empirik dengan teori yang berlaku dengan menggunakan metode deskriptif. ${ }^{8}$

Sumber data yang diperlukan adalah sumber data primer dan sekunder. Data primer didapat dan diolah oleh penulis melalui wawancara dengan pihak terkait, yaitu di kantor Kementerian Agama kota Cirebon, Kelompok Bimbingan Ibadah Haji. Adapun data sekunder melalui buku-buku, artikel, jurnal ilmiah, surat kabar cetak maupun online, dan lain-lain.

Teknik pengumpulan data yang dilakukan dalam penelitian ini adalah wawancara dan dokumentasi. Wawancara, teknik ini digunakan untuk memperoleh data-data terkait pelayanan dan penyelenggaraan ibadah haji melalui pertanyaan-pertanyaan kepada petugas atau panitia penyelenggara ibadah haji kantor Kementerian Agama kota Cirebon. Dokumentasi, pengumpulan data relevan melalui arsip-arsip, catatan-catatan termasuk perundang-undangan yang berlaku yang berhubungan dengan penelitian ini.

Dalam suatu penelitian sangat diperlukan suatu analisis data yang bermanfaat untuk memberikan jawaban terhadap permasalahan yang diteliti. ${ }^{9}$ Analisis data adalah proses mengatur urutan data, mengorganisasikan kedalam suatu pola, kategori dan satuan uraian dasar. Sedangkan metode kualitatif merupakan prosedur penelitian yang menghasilkan data deskriptif berupa kata-kata tertulis atau tidak tertulis dari orang-orang dan perilaku yang dapat diamati. ${ }^{10}$ Setelah data dari lapangan terkumpul, maka peneliti akan mengolah

${ }^{8}$ Lexy J. Moleong, Metode Penelitian Kualititaif (Bandung: Remaja Rosda Karya, 2004), 131.

${ }^{9}$ Burhan Bungi, Analisa Data Penelitian Kualitatif, Pemahaman Filosofis dan Metodologis Kearah Penguasaan Modal Aplikasi (Jakarta: PT. Raja Grafindo Persada, 2003), 53

${ }^{10}$ Lexy J. Moleong, Metode Penelitian Kualitatif, 103. dan menganalisis data tersebut dengan menggunakan metode kualitatif deskriptif.

\section{KONSEP DASAR}

\section{Konsep Haji dan Penyelenggaraaan Haji}

Haji menurut bahasa ialah menuju ke tempat berulang kali atau menuju kepada sesuatu yang dibesarkan. Baitullah merupakan tempat yang dibesarkan, oleh karena itu pekerjaan mengunjunginya dinamakan dengan haji. ${ }^{11}$ Ibnu Al-Humam ${ }^{12}$ mengatakan, haji adalah pergi menuju Baitul Haram untuk menunaikan aktivitas tertentu pada waktu tertantu. Tempat-tempat tertentu yang dimaksud adalah Ka'bah di Mekah, Shafa dan Marwa, Muzdalifah, dan Arafah. ${ }^{13}$ Menurut pendapat jumhur ulama ibadah haji difardhukan pada tahun keenam hijriyah, seiring turunnya ayat ${ }^{14}$ berikut:

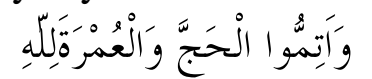

Artinya: Dan sempurnakanlah haji dan umrah untuk Allah. ${ }^{15}$

Hal tersebut berlandaskan pada pemikiran bahwa yang dimaksud dengan penyempuranaan adalah permulaan kewajban. ${ }^{16}$ Dan dalam pendapat lain menyebutkan bahwa yang dimaksudkan dengan sempurnakanlah di sini ialah kerjakanlah atau laksanakanlah. ${ }^{17}$ Ibadah

${ }^{11}$ Tengku Muhammad Hasbi Ash-Shiddieqy, Pedoman Haji (Semarang: PT. Pustaka Rizki Putra, 1998), 2.

${ }^{12}$ Ibnu Al-Humam adalah ahli hukum dan tolog Hanafi Mesir dan ditunjuk sebagai Kepala Syekh dari Khanawah Shaykhuniyyah di Kairo pada 1443, sumber: Kamus Islam Oxford, www.oxfordislamicstudies.com/article/opr/t125/e925 Diakses pada tanggal 16 Juli 2018.

${ }^{13}$ Abdul Aziz Muhammad Azam dan Abdul Wahhab Sayyed Hawwas, Fiqh Ibadah: Thaharah, Shalat, Zakat, Puasa, dan Haji (Jakarta: Amzah, 2013), 482.

${ }^{14}$ Abdul Aziz Muhammad Azam dan Abdul Wahhab Sayyed Hawwas, Fiqh Ibadah: Thaharah, Shalat, Zakat, Puasa, dan Haji, 486.

${ }^{15}$ QS. Al-Baqarah (2): 196.

${ }^{16}$ Abdul Aziz Muhammad Azam dan Abdul Wahhab Sayyed Hawwas, Fiqh Ibadah: Thaharah, Shalat, Zakat, Puasa, dan Haji, 486.

${ }^{17}$ Tengku Muhammad hasbi Ash Shiddieqy, Pedoman Haji, 6. 
haji juga terdapat dalam syariat-syariat yang lain. Ada yang mengatakan bahwasannya Adam berulangkali mengerjakan haji, Jibril memberitahukan kepada Adam bahwa malaikat bertawaf di keliling Ka'bah, dan Nabi Ibrahim juga mengerjakan haji. Menurut sebagian ulama semua nabi mengerjakan haji. Diantara ayat-ayat yang melandaskan bahwasannya haji telah ada sebelum Islam. ${ }^{18}$ Ayat yang dimaksud yaitu:

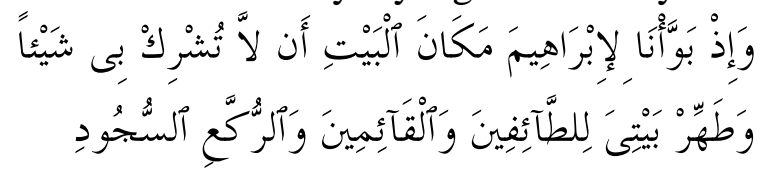

Artinya: Dan ingatlah ketika kami jadikan untuk Ibrahim tempat al-Bait, kepadanya Kami titahkan: "Hai Ibrahim, janganlah engkau menyekutukan sesuatu dengan-Ku dan sucikanlah rumah-Ku untuk orang-orang yang Tawāf, iktikaf, rukuk dan sujud". ${ }^{19}$

Untuk masyarakat yang ingin melakukan pendaftaran ibadah haji, harus memperhatikan syarat-syarat yang telah ditentukan. ${ }^{20}$

Adapun syarat pendaftaran haji, diantaranya:

1. Beragama Islam

2. Sehat jasmani dan rohani yang dibuktikan dengan surat keterangan dari dokter.

3. Memiliki Kartu Tanda Penduduk (KTP) yang masih berlaku.

4. Memiliki Kartu Keluarga.

5. Memiliki Akte Kelahiran atau surat kenal lahir atau Buku Nikah atau Ijazah (bila tidak punya bisa diganti surat keterangan dari camat).

6. Apabila jamaah haji sudah punya paspor yang masih berlaku pada point $\mathrm{d}$

\footnotetext{
${ }^{18}$ Tengku Muhammad hasbi Ash Shiddieqy, Pedoman Haji, 7.

${ }^{19}$ QS. Al-Hajj (22): 26.

${ }^{20}$ Wawancara dengan bapak Jajang Badruzaman (selaku Kepala Seksi haji kantor Kementerian Agama kota Cirebon.tanggal 18 Mei 2018.
}

dan e diganti dengan photo copy paspor dengan menunjukan paspor aslinya.

7. Memiliki tabungan untuk setoran awal diatas Rp. 25.000.000-, (dua puluh lima juta rupiah). ${ }^{21}$

Adapun prosedur pendaftaran ibadah haji sebagai berikut:

1. Calon jamaah haji membuka tabungan haji pada Bank Penerima Setoran Biaya Penyelenggaraan Ibadah Haji (BPS BPIH) dengan saldo diatas 25 juta.

2. Calon jamaah haji menandatangani surat pernyataan memenuhi persyaratan pendaftaran haji yang diterbitkan oleh Kementerian Agama RI.

3. Calon jamaah haji melakukan transfer ke rekening Menteri Agama sebesar setoran awal BPIH.

4. BPS BPIH menerbitkan lembar bukti setoran awal yang berisi nomor validasi.

5. Calon jamaah haji yang bersangkutan wajib menyerahkan persyaratan pendaftaran kepada petugas kantor Kementerian Agama kabupaten/kota paling llambat 5 (lima) hari kerja setelah pembayaran setoran awal BPIH.

6. Calon jamaah haji mengisi formulir pendaftaran haji berupa Surat Pendaftaran Pergi Haji (SPPH) untuk dilakukan verifikasi berkas dan di entry pada aplikasi Sistem Komputerisasi Haji Terpadu (SISKOHAT).

7. Petugas kantor Kementerian Agama melakukan pengambilan foto dan sidik jari calon jamaah haji yang bersangkutan.

8. Calon jamaah haji menerima lembar bukti pendaftaran haji yang tercantum nomor porsi dan telah ditandatangani oleh petugas kantor Kementerian Agama kabupaten/kota. ${ }^{22}$

\footnotetext{
${ }^{21}$ https://kemenag.go.id/berita/info_grafis_re ad/8/tata-cara-dan-persyaratan-pendaftaran-hajireguler. Diakses pada tanggal 21 Mei 2018.

${ }^{22} \mathrm{https}$ ://jabar.kemenag.go.id/artikel-41836prosedur. Diakses pada tanggal 23 Mei 2018.
} 
Dengan adanya penetapan prosedur pendaftaran ibadah haji, maka akan membantu masyarakat dalam melakukan pendaftaran ibadah haji dan mempermudah calon jamaah haji memenuhi syarat untuk melakukan pendaftaran ibadah haji. Penyelenggaraan ibadah haji merupakan tugas nasional, kegiatan penyelenggaraan ibadah haji menjadi tanggung jawab pemerintah. Pemerintah yang bertanggung jawab dalam hal pelaksanaan penyelenggaraan ibadah haji adalah Kementerian Agama. Namun, pasrtisipasi masyarakat merupakan bagian yang tidak terpisahkan dari sistem dan manajemen penyelenggaraan ibadah haji. ${ }^{23}$ Begitu pula keuangan haji adalah semua hak dan kewajiban pemerintah yang dapat dinilai dengan uang terkait dengan penyelenggaraan ibadah haji serta semua kekayaan dalam bentuk uang atau barang yang dapat dinilai dengan uang sebagai akibat pelaksanaan hak dan kewajiban tersebut, baik yang bersumber dari jamaah maupun sumber lain yang sah dan tidak mengikat. ${ }^{24}$

Namun di awal tahun 2018 Kementerian Agama tidak lagi mengelola dana haji, hal tersebut sesuai dengan Peraturan Pemerintah (PP) No 5 Tahun 2018 tentang Pelaksanaan Undang-Undang Nomor 34 Tahun 2014 tentang Pengelolaan Keuangan Haji. Dalam PP yang telah ditandatangani oleh Presiden Joko Widodo pada 13 Februari 2018 tersebut, dana haji resmi dikelola oleh Badan Pengelola Keuangan Haji (BPKH). Bukan hanya memegang dana pelaksanaan ibadah haji, BPKH juga nantinya akan mengelola dana efisiensi penyelenggaraan ibadah haji. Selain itu, tertuang juga tata cara pengeluaran penempatan, dan investasi

\footnotetext{
${ }^{23}$ Undang-Undang Republik Indonesia Nomor 13 Tahun 2008 tentang Peyelenggaraan Ibadah Haji, (Jakarta: Sekertaris Negara, 2008).

${ }^{24}$ Pasal 1 ayat (1) Undang-Undang Republik Indonesia Nomor 34 Tahun 2014 tentang Pengelolaan Keuangan Haji.
}

keuangan haji yang bisa dilakukan oleh BPKH. ${ }^{25}$

\section{Akad Penyelenggaraan Ibadah Haji}

Kata akad berasal dari bahasa Arab al- 'aqd yang secara etimologi berarti perikatan, perjanjian, dan pemufakatan. Secara terminologi fiqh, kata akad didefinisikan:

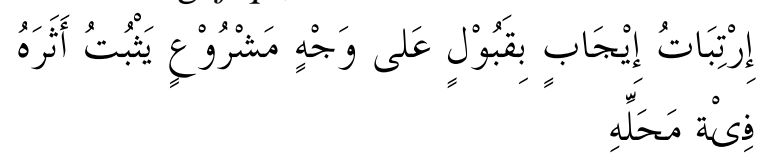

Artinya: Pertalian ijab (pernyataan melakukan ikatan) dan kabul (pernyataan penerimaan ikatan) sesuai dengan kehendak syariat yang berpengaruh pada objek perikatan. $^{26}$

Akad merupakan salah satu dari tindakan hukum. Adanya akad menimbulkan akibat hukum terhadap objek hukum yang diperjanjikan oleh para pihak dan juga memberikan konsekuensi hak dan kewajiban yang mengikat para pihak. ${ }^{27}$ Tiga unsur yang terkandung dalam akad, ${ }^{28}$ yaitu pertalian ijab (pernyataan kehendak oleh satu pihak/mujib) dan kabul (pernyataan menerima atau menyetujui kehendak mujib tersebut oleh pihak lainnya/qābil), dibenarkan oleh syara', mengakibatkan akibat hukum (konsekuensi hak dan kewajiban) terhadap objeknya.

\section{Rukun dan Syarat Akad}

Menurut Abdul Rahman Ghazali, Ghufron Ihsan, dan Sapiudin Shidiq, ${ }^{29}$ serta dalam pasal 22 Kompilasi Hukum Ekonomi Syariah (KHES) yang dikutip oleh Imron

${ }^{25} \mathrm{https}$ ://finance.detik.com/berita-ekonomibisnis/d-3898408/aturan-main-pengelolaan-danahaji-terbit-bisa-dipakai-apa-saja/6 diakses pada tanggal 15 Maret 2018.

${ }^{26}$ Abdul Rahman Ghazaly, et.al., Fiqh Muamalat (Jakarta: Kencana, 2012), 50-51.

${ }^{27}$ Gemala Dewi, et.al., Hukum Perikatan Islam di Indonesia (Depok: Kencana, 2005), 46.

${ }^{28}$ Gemala Dewi, et.al., Hukum Perikatan Islam di Indonesia, 45-46.

${ }^{29}$ Abdul Rahman Ghazaly, et.al., Fiqh Muamalat, 51-52. 
Rosyadi, ${ }^{30}$ rukun-rukun akad adalah sebagai berikut:

1. Pihak-pihak yang berakad (al'aqidain). 'Āqid adalah orang yang berakad. Ijab dan kabul yang oleh Hanafiah dipandang sebagai satusatunya rukun akad, timbul dari orangorang yang melakukan akad. Pihakpihak yang terlibat dalam akad dapat terdiri dari manusia dan badan hukum.

2. Objek akad (Ma'qūd 'alaih), ialah benda-benda yang diakadkan. Bentuk objek akad dapat berupa benda bewujud, seperti mobil dan rumah, maupun benda tidak berwujud, seperti manfaat.

3. Tujuan akad (Maudhū' al-'aqd), yaitu tujuan atau maksud pokok mengadakan akad, berbeda akad maka berbedalah tujuan akad. Dalam akad jual beli misalnya, tujuan pokoknya yaitu memindahkan barang dari penjual kepada pembeli dengan diberi ganti. Tujuan pokok akad hibah yaitu memindahkan dari pemberi kepada yang diberi untuk dimilikinya tanpa pengganti.

4. Kesepakatan (șigah al- 'aqd). Șigah al'aqd adalah ijab kabul. Ijab adalah pernayataan yang keluar pertama kali dari salah seorang yang melakukan akad, baik ia pemilik barang maupun calon pemilik barang. Sedangkan kabul adalah pernyataan yang dikeluarkan belakangan sebagai jawaban atas pernyataan pertama, dengan tidak memandang siapa yang menyatakannya.

Secara global, syarat dilihat dari sumbernya terbagi kepada dua bagian:

1. Syarat Syar'i yaitu syarat yang ditetapkan oleh syara', yang harus ada untuk bisa terwujudnya suatu akad.

\footnotetext{
${ }^{30}$ Imron Rosyadi, Jaminan Kebendaan Berdasarkan Akad Syariah (Aspek Perikatan, Prosedur Pembebanan dan Eksekusi) (Depok: Kencana, 2017), 4.
}

Seperti syarat ahliyah (kemampuan) pada si 'aqid untuk keabsahan akad.

2. Syarat Ja'li, yaitu syarat yang ditetapkan oleh orang yang berakad sesuai dengan kehendaknya, untuk mewujudkan suatu maksud tertentu dari suatu akad. Syarat tersebut bisa bebarengan dengan akad, digantungkan (dikaitkan) dengan akad, seperti mengaitkan kafalah dengan talak. ${ }^{31}$

\section{Macam-macam Akad}

Para ulama figh mengemukakan bahwa akad itu dapat dibagi dilihat dari beberapa segi. Jika dilihat dari segi keabsahannya menurut syara', akad terbagi menjadi dua, ${ }^{32}$ yaitu:

1. Akad Shahih, ialah akad yang telah memenuhi rukun-rukun dan syaratsyaratnya. Akad yang shahih ini dibagi lagi oleh ulama Hanafiyah dan Malikiyah menjadi dua macam, yaitu:

a. Akad yang nafiz (sempurna untuk dilaksanakan), ialah akad yang dilangsungkan dengan memenuhi rukun dan syaratnya dan tidak ada penghalang untuk melaksanakannya.

b. Akad mawquf, ialah akad yang dilakukan seseorang yang cakap bertindak hukum, tetapi ia tidak memiliki kekuasaan untuk melaksanakan akad ini, seperti akad yang dilangsungkan oleh anak kecil yang mumayyiz.

2. Akad yang tidak Shahih, yaitu akad yang terdapat kekurangan pada rukun atau syarat-syaratnya, sehingga seluruh akibat hukum-hukum akad itu tidak berlaku dan tidak mengikat pihak-pihak yang berakad. Ulama Hanafiah membagi akad yang tidak shahih ini kepada dua macam, yaitu akad yang batil dan fasid. Suatu akad dikatakan batil apabilla akad itu tidak memenuhi

${ }^{31}$ Ahmad Wardi Muslich, Fiqh Muamalat (Jakarta: Amzah, 2010), 150.

${ }^{32}$ Abdul Rahman Ghazaly, et.al., Fiqh Muamalat, 55-58. 
salah satu tukunnya atau ada larangan langsung dari syara'. Adapun akad fasid merupakan suatu akad yang pada dasarnya disyariatkan, akan tetapi sifat yang diakadkan itu tidak jelas. Namun menurut jumhur ulama fiqh menyatakan bahwa akad yang batil dan fasid mengandung esensi yang sama, yaitu tidak sah dan akad itu tidak mengakibatkan hukum apapun.

Ditinjau dari segi penamaannya, para ulama fiqh membagi akad kepada dua macam, yaitu:

1. Al-'Uqud al-musamma, yaitu akad yang ditentukan namanya oleh syara' serta dijelaskan hukumnya, seperti jual beli, ijarah, wakalah, hiwalah, dan lain-lain.

2. Al-'Uqud ghair al-musamma, ialah akad-akad yang penamaannya dilakukan oleh masyarakat sesuai dengan keperluan mereka disepanjang zaman dan tempat, seperti al-istishna dan ba'i al-wafa.

\section{Akibat Hukum Akad}

Akad merupakan salah satu dari tindakan hukum. Adanya akad menimbulkan akibat hukum terhadap objek hukum yang diperjanjikan oleh para pihak dan juga memberikan konsekuensi hak dan kewajiban yang mengikat para pihak. ${ }^{33}$ Menurut Ahmad Azhar Basyir yang dikutip oleh Iyah Faniyah, ${ }^{34}$ hak dan kewajiban adalah dua sisi yang saling bertimbal balik dalam suatu transaksi. Hak salah satu pihak merupakan kewajiban bagi pihak lain, begitu pula sebaliknya kewajiban salah satu pihak menjadi hak bagi pihak lain. Keduanya saling berhadapan dan diakui dalam hukum. Dalam hukum Islam, hak adalah kepentingan yang ada pada perorangan atau masyarakat, atau pada keduanya, yang diakui oleh syara'.

\footnotetext{
${ }^{33}$ Gemala Dewi, et.al., Hukum Perikatan Islam di Indonesia, 46.

${ }^{34}$ Iyah Faniyah, Kepastian Hukum Sukuk Negara Sebagai Instrumen Investasi di Indonesia (Yogyakarta: Deepublish, 2018), 116.
}

Berhadapan dengan hak seseorang terdapat kewajiban orang lain untuk menghormatinya.

Berbeda dengan rukun Islam yang lainnya seperti syahadat ataupun shalat yang hanya dinilai sebagai ibadah, haji bukan hanya dinilai sebagai bentuk ritual ibadah saja namun juga bisa dilihat dalam aspek atau sisi-sisi muamalah. Hal tersebut dikarenakan dalam melaksanakan ibadah haji diperlukan persiapan yang melibatkan banyak sektor pendukung. Dengan diperlukannya persiapan yang melibatkan banyak sektor pendukung, maka dalam pelaksanaan ibadah haji timbullah akad antara calon jamaah haji dengan pihak-pihak yang terkait. Dalam penyelenggaraan ibadah haji ada beberapa akad, diantaranya:

1. Wakālah

\section{a. Pengertian Wakālah}

Wakālah artinya perwakilan. Wakālah ialah penyerahan dari seseorang kepada orang lain untuk mengerjakan sesuatu, perwakilan berlaku selama yang mewakilkan masih hidup. ${ }^{35}$ Menurut Ismail Nawawi ${ }^{36}$ secara bahasa wakālah atau wakilah berarti at-Tafwidh (penyerahan, pendelegasian dan pemberian mandat).Sementara menurut istilah, al-Syarbini mendefinisikan wakālah:

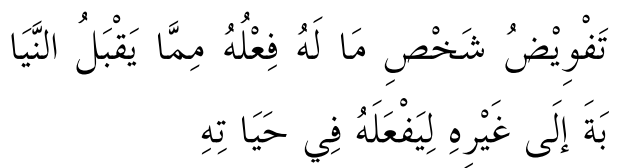

Artinya: Penyerahan kewenangan seseorang yang dapat dilimpahkan kepada orang lain, agar ia melaksanakan kewenangan tersebut dalam hidupnya.

\footnotetext{
${ }^{35}$ Hendi Suhendi, Fiqh Muamalah (Jakarta: RajaGrafindo, 2005), 233.

${ }^{36}$ Ismail Nawawi, Fikih Muamalah Klasik dan Kontemporer Hukum Perjanjian, Ekonomi, Bisnis, dan Sosial, 211.
} 
Dalam pasal 20 ayat (19) Kompilasi Hukum Ekonomi Syari'ah (KHES), mendefinisikan wakalah sebagai pemberian kuasa kepada pihak lain untuk mengerjakan sesuatu. Kuasa dalam konteks ini kuasa untuk menjalankan kewajiban dan juga kuasa untuk menerima hak. ${ }^{37}$

b. Dasar Hukum Wakālah ${ }^{38}$

Wakālah disyariatkan berlandaskan al-Qur'an, al-Sunnah, dan ijma'. Antara lain adalah sebagai berikut:

1) Dasar hukum dalam al-Qur'an tertuang pada surat al-Kahfi ayat 19 , berikut ini:

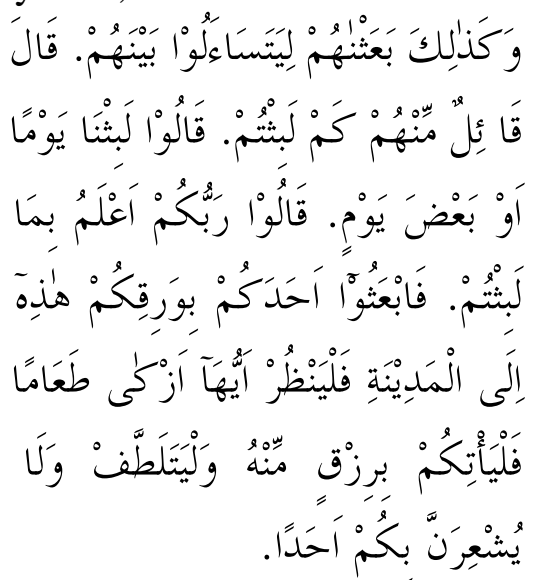

2) Dasar hukum dalam al-Sunnah

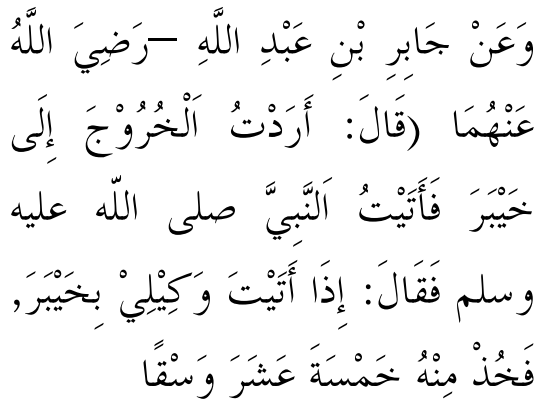

Artinya: Dari Jabir bin Abdillah ra. berkata, Aku hendak berangkat ke Khaibar, lalu aku menemui Nabi SAW. beliau bersabda, "Jika engkau

\footnotetext{
${ }^{37}$ Imam Mustafa, Fiqih Mu'amalah Kontemporer (Jakarta: RajaGrafindo Persada, 2016), 206.

${ }^{38}$ Imam Mustafa, Fiqih Mu'amalah Kontemporer, 207-209.
}

menemui wakilku di Khaibar, ambillah olehmu darinya lime belas wasaq.

3) Dasar hukum dalam ijma'

Ulama bersepakat mengenai diperbolehkannya wakālah, karena sangat dibutuhkan dalam kehidupan manusia. Selain itu, wakālah juga dapat menjadi sarana untuk saling membantu dan menolong sesama manusia.

c. Rukun dan Syarat Wakālah ${ }^{39}$

Ada beberapa rukun dan syarat yang harus dipenuhi dalam wakālah, diantaranya:

1) Orang yang mewakilkan (muwakkil), syaratnya dia berstatus sebagai pemilik urusan/benda dan menguasainya serta dapat bertindak terhadap harta tersebut dengan dirinya sendiri.

2) Orang yang mewakili (wakīl), syaratnya ialah orang yang berakal. Jika ia idiot, gila, atau belum dewasa maka batal. Tapi menurut Hanafiyah anak kecil yang cerdas (dapat membedakan yang baik dan buruk) sah menjadi wakil.

3) Sesuatu yang diwakilkan (muwakkil fih), syaratnya pekerjaan/ urusan itu dapat diwakilkan atau digantikan

\footnotetext{
${ }^{39}$ Artinya: Dan demikianlah kami bangunkan mereka, agar diantara mereka saling bertanya. Salah seorang diantara mereka berkata, "sudah berapa lama kamu (di sini)?" Mereka menjawab, "Kita berada (di sini) sehari atau setengah hari. "Berkata (yang lain lagi), "Tuhanmu lebih mengetahui berapa lama kamu berada (di sini). Maka suruhlah salah seorang diantara kamu untuk pergi ke kota dengan membawa yang perakmu ini, dan hendaklah dia lihat manakah makanan yang lebih baik, maka hendaklah ia membawa makananmakanan itu untukmu, dan hendaklah dia berlaku lemah lembut dan jangan sekali-kali menceritakan halmu kepada siapapun. Lihat Abdul Rahman Ghazaly, et.al., Fiqh Muamalat, 189.
} 
oleh orang lain. Oleh karena

itu, tidak sah untuk mewakilkan untuk mengerjakan ibadah seperti shalat, puasa, dan membaca alQur'an.

\section{Wadī'ah}

a. Pengertian Wad'̄'ah

Kata wad'̄ah berasal dari kata wada'a asy-syaia, yaitu meninggalkan sesuatu. Disebut wad'̄ah karena sesuatu yang ditinggalkan seseorang kepada orang lain untuk dijaga. ${ }^{40}$ Menurut al-Syarwani, sebagaimana dikutip Imam Mustafa $^{41}$ bahwa secara terminologi wadī'ah merupakan:

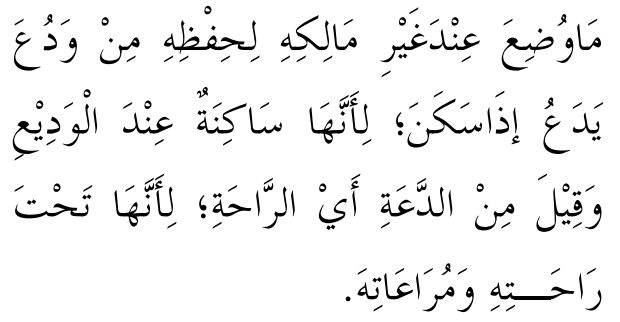

b. Dasar Hukum Wadī'ah

1) Dasar hukum dalam alQur'an tertera dalam QS. alBaqarah (2) ayat $283,{ }^{42}$ sebagai berikut:

\footnotetext{
${ }^{40}$ Hasbiyallah, Sudah Syar'ikah Muamalahmu? Panduan Memahami Seluk-Beluk Fiqh Muamalah (Yogyakarta: Salma Idea, 2014), 57.

${ }^{41}$ Wad̄̄'ah secara bahasa adalah barang yang diletakkan atau diserahkan kepada orang lain untuk dijaga, wadīah berasal dari kata wadu'a, yada'u, yang berarti ketika berada di suatu tempat, karena barang yang berada di tempat orang yang dititipi, ada yang mengatakan wadī'ah berasal dari kata 'al$d a$ 'ah' yang berarti istirahat, karena barang tersebut berada di tempat penyimpanan atau tempat peristirahatan milik orang yang menerima titipan. Lihat Imam Mustafa, Fiqih Mu'amalah Kontemporer, 179.

${ }^{42}$ Artinya: Jika sebagian kamu memercayai sebagian yang lain, maka hendaklah yang dipercayai itu menunaikan amanatnya dan hendaklah ia bertakwa kepada Allah Tuhannya. Lihat Hasbiyallah, Sudah Syar'ikah Muamalahmu? Panduan Memahami Seluk-Beluk Fiqh Muamalah, 57.
}

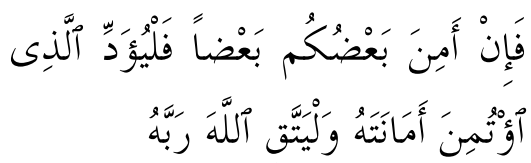

2) Dasar Hukum dalam Hadis ${ }^{43}$ yang diriwayatkan dari Abu Hurairah r.a.:

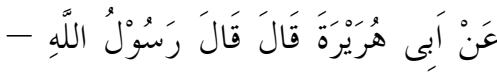

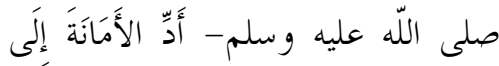

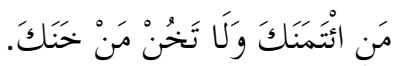

$$
\begin{aligned}
& \text { Artinya: Dari Abu } \\
& \text { Hurairah r.a. } \\
& \text { berkata, Rosulullah } \\
& \text { SAW. bersabda } \\
& \text { tunaikanlah } \\
& \text { amanah yang } \\
& \text { mempercayakan } \\
& \text { kepadamu dan } \\
& \text { janganlah engkau } \\
& \text { hianati orang yang } \\
& \text { menghianatimu. }
\end{aligned}
$$

3) Ijma'

Landasan dari ijma' adalah kesepakatan ulama. Ulama bersepakat mengenai diperbolehkannya wad'’ah, karena umumnya masyarakat sangat membutuhkan akad wadīah. Adanya akad wad'i'ah sangat membantu manusia untk saling membantu dalam menjaga harta yang juga menjadi tujuan agama.

c. Rukun dan Syarat Wadī'ah

Rukun akad wad'̄ah menurut jumhur ulama, yaitu dua orang yang melakukan akad, sesuatu yang dititipkan,

\begin{tabular}{llll}
\hline $\begin{array}{c}{ }^{43} \text { Imam } \\
\text { Kontemporer, } 181 . \\
\text { M4 Imam } \\
\text { Kontemporer, } 182 .\end{array}$ & Mustafa, & Fiqih & Mu'amalah \\
& & Fiqih & Mu'amalah \\
& &
\end{tabular}


dan shigat (ijab dan kabul). ${ }^{45}$ Kompilasi Hukum Ekonomi Syariah pasal $370,{ }^{46}$ menyebutkan rukun wadī'ah adalah muwaddi' (penitip), mustauda' (penerima titipan), wadì'ah bih (harta titipan), dan akad.

atas mempunyai rukun di Menurut kalangan Hanbaliyah dan mayoritas ulama, syarat dan akad wadī'ah sama dengan akad wakālah, yaitu pihak yang melakukan akad harus baligh dan cakap hukum. Sementara barang yang dititipkan adalah barang yang secara syar'i tidak dilarang, barang harus dapat diserahterimakan.

d. Jenis Wad'̄'ah

$$
\text { Menurut Wiroso, }{ }^{47}
$$
wad'̄'ah terdiri dari dua jenis, yaitu wadì'ah yad al amanah dan wadi' ah yad al dhamanah.

1) Wadī'ah yad al amanah, dengan karakteristik yang merupakan titipan murni di mana barang yang dititipkan tidak boleh digunakan (diambil manfaatnya) oleh penitip, dan sewaktu titipan dikembalikan harus dalam keadaan utuh baik nilai maupun fisik barangnya, serta jika selama dalam penitipan barang terjadi kerusakan maka pihak yang menerima titipan

\footnotetext{
${ }^{45}$ Hasbiyallah, Sudah Syar'ikah

Muamalahmu? Panduan Memahami Seluk-Beluk Fiqh Muamalah, 58.

${ }^{46}$ Imam Mustafa, Fiqih Mu'amalah Kontemporer, 182-183.

${ }^{47}$ Wiroso, Penghimpunan Dana dan Distribusi Hasil Usaha Bank Syariah (Jakarta: Grasindo, 2005), 22-23.
}

tidak dibebani tanggung jawab, sedangkan sebagai kompensasi atas tanggung jawab pemeliharaan dapat dikenakan biaya titipan.

2) Wadì'ah yad al dhamanah, dengan karakteristik yaitu merupakan pengembangan wad'̈ah yad al amanah yang disesuaikan dengan aktivitas perekonomian. Penerima titipan diberi izin untuk menggunakan dan mengambil manfaat dari titipan tersebut. Penyimpan mempunyai kewajiban untuk bertanggung jawab terhadap kehilangan/kerusakan barang tersebut. Semua keuntungan yang diperoleh dari titipan tersebut menjadi hak penerima titipan. Sebagai imbalan kepada pemilik barang/dana dapat diberikan semacam intensif berupa bonus yang tidak dipersyaratkan sebelumnya.

Karakteristik Wadī'ah yad al dhamanah, ${ }^{48}$ yaitu a) penyimpan boleh memanfaatkan barang/uang titipan, b) Keuntungan sepenuhnya menjadi milik penyimpan, c) Penyimpan dapat memberikan intensif (bonus) kepada penitip yang tidak boleh dijanjikan dalam akad.

Dari dua jenis wadiah diatas, maka dapat diketahui bahwa kedua jenis akad wadiah pada dasarnya

\footnotetext{
${ }^{48}$ Nurul Huda dan Mohamad Heykal, Lembaga Keuangan Islam Tinjauan Teorits dan Praktis (Jakarta: Kencana, 2010), 89.
} 
memiliki kesamaan sebagai barang titipan. Perbedaan diantara keduanya adalah bahwa dalam akad wadiah yad al amanah barang yang dititipkan bersifat tidak dapat digunakam oleh pihak penerima titipan, sedangkan dala akad wadiah yad al dhamanah barang yang dititipkan bersifat boleh dan dapat digunakan oleh pihak penerima titipan.

\section{Ijārah}

\section{a. Pengertian Ijārah}

$$
\text { Ijārah artinya sewa }
$$
menyewa. Menurut istilah ijarah adalah akad untuk membolehkan pemilikan manfaat yang diketahui dan sengaja dari suatu zat yang disewa dengan imbalan. ${ }^{49}$

Menurut Sayid Sabiq seperti yang diungkapkan oleh Ahmad Wardi Muslich, ${ }^{50}$ bahwa:

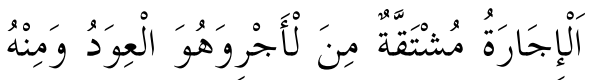

$$
\begin{aligned}
& \text { سُمِِّ الثَّوَابُ أجرًْا }
\end{aligned}
$$

Pada dasarnya tidak ada perbedaan yang prinsip diantara para ulama dalam mengartikan ijārah atau sewa menyewa, ijārah atau sewa menyewa adalah akad atas manfaat dengan imbalan. Dengan demikian objek sewa menyewa adalah manfaat atas suatu barang.

Sementara itu, Kompilasi Hukum Ekonomi Syariah (KHES) Pasal 20 mendefinisikan ijārah adalah sewa barang dalam jangka

${ }^{49}$ Hendi Suhendi, Fiqh Muamalah, 113-114.

${ }^{50}$ Kata ijārah diambil dari kata "Al-Ajr" yang artinya 'iwadh (imbalan), dari pengertian ini pahala (tsawab) dinamakan ajr (upah/pahala). Lihat Ahmad Wardi Muslich, Fiqh Muamalat, 315-317. waktu tertentu dengan pembayaran. $^{51}$

b. Dasar Hukum Ijārah

Ijārah hukum asalnya menurut jumhur ulama adalah mubah atau boleh bila dilaksanakan sesuai dengan ketentuan yang ditetapkan oleh syara' berdasarkan ayat al-Qur'an, al-Sunnah, dan ketetapan ijma' ulama. Adapun dasar hukum tentang kebolehan ijārah adalah sebagai berikut.

1) Dasar hukum dalam al-Qur'an terdapat pada surat at-Thalaq (65) ayat $6,{ }^{53}$ yaitu:

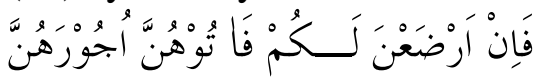

2) Dasar hukum dalam al-Sunnah

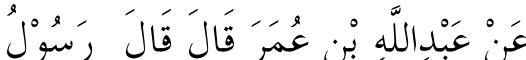

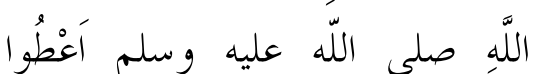

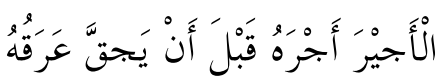

Artinya: Dari Abdullah bin Umar berkata, Rasulullah SAW. bersabda: Berikanlah upah orang yang bekerja sebelum keringatnya mengering.

3) Ijma' ulama

Perlu diketahui

bahwa tujuan disyariatkan ijārah itu adalah untuk memberi keringanan kepada umat dalam pergaulan hidup. Banyak orang yang mempunyai uang tetapi tidak dapat bekerja, dipihak lain banyak orang yang mempunyai tenaga atau

\footnotetext{
${ }^{51}$ Imam Mustafa, Fiqih Mu'amalah Kontemporer, 101-102.

${ }^{52}$ Abdul Rahman Ghazaly, et.al., Fiqh Muamalat, 277-278.

${ }^{53}$ Artinya: Jika mereka telah menyusukan anakmu, maka berilah upah mereka. QS. At-Thalaq (65): 6.
} 
keahlian yang membutuhkan uang.

c. Rukun dan Syarat Ijārah ${ }^{54}$

Umumnya dalam kitab fikih disebutkan bahwa rukun ijārah adalah pihak yang menyewa (musta'jir), pihak yang menyewakan (mu'jir), ijab dan kabul (șigah), manfaat barang yang disewakan dan upah.

d. Macam-macam Ijārah

1) Ijārah atas manfaat, disebut juga sewa menyewa. Dalam ijārah bagin pertama ini, objek akadnya adalah manfaat dari suatu benda.

2) Ijārah atas pekerjaan, disebut juga upah mengupah. Dalam ijārah bagian kedua ini, objek akadnya adalah pekerjaan seseorang. ${ }^{55}$

4. 'Urbūn (Uang Muka) ${ }^{56}$

a. Pengertian 'Urbūn (Uang Muka)

Uang muka dalam istilah fikih dikenal dengan al-'Arabūn, yang memiliki padanan kata (sinonim) dalam bahasa Arabnya yaitu 'urbūn dan 'urbān. Secara bahasa yang jadi transaksi dalam jual beli. Berkata penulis kitab alMishbah al-Munir, "al-'Arabūn dengan difathahkan huruf 'Ain dan $R a$ 'nya. Sebagian ulama menyatakan, yaitu seorang membeli sesuatu atau menyewa sesuatu dan memberikan sebagian pembayarannya atau uang sewanya kemudian menyatakan apabila transaksi sempurna kita hitung pembayaran dan bila tidak maka itu

\footnotetext{
${ }^{54}$ Imam Mustafa, Fiqih Mu'amalah Kontemporer, 102.

${ }^{55}$ Ahmad Wardi Muslich, Fiqh Muamalat, 329.

${ }^{56}$ Abdullah Afif dan Masaji Antoro, Kumpulan Tanya Jawab Keagamaan Pustaka Ilmu Sunni Salafiyah-KTB (Yogyakarta: Ttp., 2015), 2504-2506.
}

untukmu dan aku tidak meminta kembali darimu.

b. Hukum 'Urbūn (Uang Muka)

Dalam permasalahan ini para ulama berbeda pendapat, diantaranya:

1) Uang muka dalam sebuah akad adalah tidak sah Inilah pendapat mayoritas dari kalangan ulama Hanafiyah, Malikiyah, dan Syafi'iyah. Khotobi menyatakan, para ulama berselisih pendapat tentang kebolehan 'urbūn (uang muka).

a) Hadits Amru bin Syuaib, dari ayahnya, dari kakeknya bahwa ia berkata:

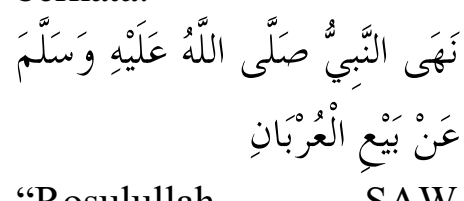

"Rosulullah SAW. melarang jual belli dengan sistem uang muka." ( H.R. Abu Daud dan didhaifkan oleh Ibn Hajar).

b) 'Urbūn (uang muka) itu termasuk memakan harta orang lain dengan cara batil, karena perkiraan salah satu pihak tidak ridha.

2) 'Urbūn (uang muka) diperbolehkan

$$
\text { Kalangan Hambali }
$$

memandang 'urbūn sebagai sesuatu yang sah dan tidak bertentangan dengan hukum Islam dan memandang hadits pelarangan 'urbūn kedudukannya lemah. Dalam sumber lain menjelaskan, Wahbah az-Zuhaili ${ }^{57}$

${ }^{57}$ Harun, Fiqh Muamalah (Surakarta: Muhammadiyah University Press, 2017), 73. 


$\begin{aligned} & \text { membenarkan } \\ & \text { pembayaran uang } \\ & \text { dengan dalil } \text { 'urf } \\ & \text { kebiasaan). }\end{aligned}$

5. Ijārah maușūffì Żimmah

Akad ijārah maușūf fì zimmah adalah akad sewa menyewa atas manfaat suatu barang atau jasa yang pada saat akad hanya disebutkan sifatsifat, kuantitas, dan kualitasnya (spesifikasi). ${ }^{58}$

Ahmad Muhammad Mahmud Nashar, ${ }^{59}$ menjelaskan sebagai berikut:

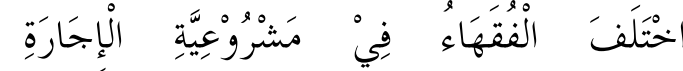

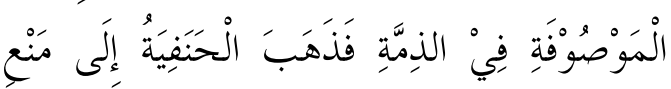

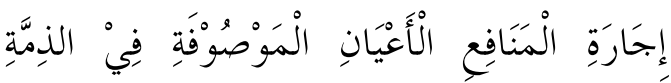

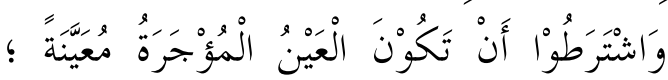

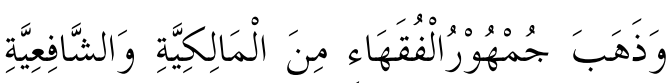

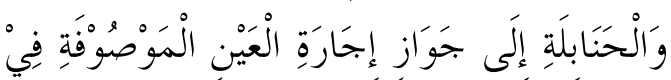

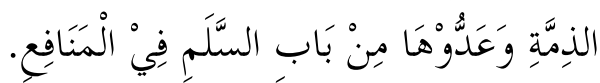

Artinya: Ahli fikih berbeda pendapat tentang status hukum ijārah maușüf $f_{i}$ zimmah; pertama, ulama Hanafiyyah berpendapat bahwa akad ijārah atas manfaat barang yang termasuk maușūf fi zimmah adalah akad yang dilarang; mereka berpendapat bahwa barang sewa harus sudah ditentukan pada saat akad atau perjanjian dilakukan; dan kedua, jumhur ulama dari kalangan Malikiyyah, Syafi'iyyah, dan Hanabilah membolehkan akad ijārah atas barang yang termasuk maușüf fì zimmah; mereka menganggap akad ijārah maușūf fi zimmah ini bagian dari bentuk akad jual-beli salam atas manfaat.

\footnotetext{
${ }^{58}$ www.infosyariah.com/2016/12/ijarahmaushufah-fi-al-zimmah-imfz.html?m=1. Diakses pada tanggal 1 Agustus 2018.

${ }_{59}^{5 w w . i n f o s y a r i a h . c o m / 2016 / 12 / i j a r a h-~}$ maushufah-fi-al-zimmah-imfz.html?m=1. Diakses pada tanggal 12 Agustus 2018.
}

Fatwa Dewan Syariah Nasional Nomor 101/DSN-MUI/X/2016 tentang Akad Al-Ijarah Al-Maushufah fi AlDzimmah, ${ }^{60}$ membolehkan akad ijārah maușūf fi zimmah dengan mengikuti ketentuan dalam fatwa ini, akad ijārah maușūf fi zimmah berlaku secara efektif dan menimbulkan akibat hukum baik secara khusus (tujuan akad) maupun akibat hukum umum yaitu hak dan kewajiban sejak akad dilangsungkan.

\section{PEMBAHASAN DAN DISKUSI}

\section{Akad Penyetoran Dana Awal Biaya Penyelenggaraan Ibadah Haji (BPIH)}

Banyak yang belum mengetahui secara jelas tentang akad yang digunakan dalam penyelenggaraan haji khususnya dalam penyetoran dana awal BPIH, baik dari pihak masyarakat maupun pihak Kementerian Agama Kota. Hal tersebut disebabkan karena pada saat penyetoran uang ke bank tidak ada akad tertulis.

Namun, pernyataan Menteri Agama Lukman Hakim Syaifuddin yang dikutip Kompas.com tentang akad saat membayar ongkos haji ke kementerian agama adalah wakalah. ${ }^{61}$ Begitu juga yang disampaikan oleh Direktur Pengelolaan Dana Haji dan Sistem Informasi Haji Terpadu Kemenag Ramadan Harisman yang dikutip oleh Khoiron, ${ }^{62}$ bahwa pemanfaatan Biaya Penyelenggaraan Ibadah Haji (BPIH) untuk pembangunan maupun investasi tidak perlu meminta izin lagi kepada jemaah, sebab ketika pengelolaan dana haji dilakukan oleh Kementerian Agama para calon jemaah haji telah mengisi dan menandatangani formulir akad wakalah ketika membayar setoran awal

${ }^{60}$ Fatwa Dewan Syariah Nasional Nomor 101/DSN-MUI/X/2016 tentang Akad Al-Ijarah AlMaushufah fi Al-Dzimmah, (Jakarta: Sekretaris DSN-MUI, 2016).

${ }^{61} \mathrm{https}: / /$ edukasi.kompas.com/read/2017/08/ 01/18265581/mengenal-akad-wakalah-dan-prinsipdana-haji. Diakses pada tangal 2 Agustus 2018.

${ }^{62} \mathrm{https} / / / \mathrm{kemenag.go.id/berita/read} / 505045 / \mathrm{s}$ udah-akad-wakalah-pengelolaan-bpih-tak-harus-izinjemaah-lagi. Diakses pada tanggal 2 Agustus 2018. 
BPIH. Menurut Ramadan Harisman, ketentuan pengisian dan penandatangan akad wakalah tersebut diatur dalam Perjanjian Kerja Sama antara Ditjen Penyelenggara Haji dan Umrah, Kementerian Agama, dengan pihak Bank Penerima Setoran BPIH tentang penerimaan dan pembayaran BPIH.

Penulis menela'ah, jika akad dalam penyetoran dana awal BPIH menggunakan akad wakalah berarti pemerintah hanya sebagai wakil, bukan pihak yang berakad, maka dalam pemenuhan kebutuhan persiapan penyelenggaraan ibadah haji baik berupa akomodasi, transportasi, kesehatan, maupun yang lainnya, jamaah haji seharusnya berhubungan langsung dengan pihak ketiga sebagai penyedia hal-hal tersebut tadi. Namun, dalam prakteknya yang jamaah haji ketahui segala persiapan tersebut adalah pemerintah yang menyediakan dalam hal ini Kementerian Agama, tanpa mengetahui pihak ketiga atau pihak yang menyediakan hal-hal tersebut tadi. Oleh karena itu, menurut pendapat penulis penggunaan akad wakalah dalam penyetoran dana awal BPIH belum sesuai.

Menurut Irfan Syauqi Beik ${ }^{63}$, akad wakalah bukan harga mati karena tidak tersebut eksplisit dalam Undang-Undang No 34 tahun 2014 tentang Pengelolaan Keuangan Haji. Meskipun pemerintah mengatakan menggunakan akad wakalah, namun masih dimungkinkan untuk menggunakan akad lain, seperti ijārah maushüf fi dzimmah (IMFD), sebagaimana yang pernah dibahas dalam Ijtima Komisi Fatwa MUI tahun 2012, dua tahun sebelum lahirnya UU tentang Pengelolaan Keuangan Haji.

Untuk mengetahui lebih jelas jenis akad apa yang digunakan, maka penulis mencoba menelaah dengan melihat kembali

\footnotetext{
${ }^{63}$ Kepala Pusat Studi Bisnis dan Ekonomi Syariah (CIBEST) IPB, dikutip dari https://m.republika.co.id/berita/jurnalismewarga/wacana/17/07/31/otxeib396-sulusi-ataspolemik-dan-haji diakses pada tanggal 8 Agustus 2018.
}

prosedur pendaftaran haji, dalam penyetoran dana awal BPIH calon jamaah haji melakukan transfer ke rekening Menteri Agama melalui Bank Penerima Setoran (BPS) BPIH. Hal tersebut berarti bahwa terjadi akad wakalah antara calon jamaah haji dan BPS BPIH , dimana pihak BPS BPIH merupakan wakil calon jamaah haji untuk menyerahkan uang setoran ke Kementerian Agama. Selain itu, pada tahap itu juga menjelaskan bahwa uang setoran dana awal BPIH langsung diserahkan ke pihak Kementerian Agama, hal tersebut menggambarkan bahwa calon jamaah haji menitipkan uang setoran dana awal BPIH ke pihak Kementerian Agama, dan merupakan gambaran akad wadī'ah. Dimana calon jamaah haji sebagai pemilik dana menitipkan sejumlah uang kepada pihak Kementerian Agama, dan Kementerian Agama sebagai pihak penerima titipan.

Berdasarkan pendapat-pendapat yang sudah penulis tampung dan uraian prosedur pendaftaran haji di atas, menurut penulis akad yang digunakan pada saat penyetoran dana awal BPIH adalah akad wadi'ah (titipan) antara calon jamaah haji dan pihak Kementerian Agama. Karena pada saat penyetoran dana awal, calon jamaah haji hanya menyetorkan uang sebagai bentuk keseriusan calon jamaah untuk mendaftar haji, dan uang tersebut nominalnya tetap sampai waktu tunggu panggilan calon jamaah untuk berangkat. Kemudian pada saat calon jamaah haji menerima panggilan untuk berangkat, calon jamaah melunasi biaya penyelenggaraan ibadah haji yang telah ditetapkan pemerintah pada tahun jamaah haji berangkat. Dan pada saat pelunasan biaya penyelenggaraan ibadah haji tersebut, menurut pendapat penulis timbulah akad al-ijārah al-maushūf fì aldzimmah, karena pada saat itu jamaah haji mempercayai pihak pemerintah dalam hal ini Kementerian Agama sebagai pihak penyedia jasa peneyelenggaraan ibadah haji, dimana akad al-ijārah al-maushūf fì aldzimmah merupakan jual beli salam atas manfaat. 
Hak Jamaah Haji atas Pengelolaan Dana Setoran Awal Biaya Penyelenggaraan Ibadah Haji (BPIH)

Dalam penyetoran dana Awal BPIH, pendapat penulis adalah menggunakan akad wadī'ah yad al dhamanah. Maka jamaah haji tidak berhak atas hasil pengelolaan setoran awal BPIH. Namun bila pihak penerima titipan dalam hal ini Kemneterian Agama ingin memberikan atau membagi hasil pengelolaan dana tersebut, maka diperbolehkan dengan bentuk sebagai imbalan kepada jamaah haji sebagai pemilik dana berupa bonus yang tidak disyaratkan sebelumnya. Selain itu, pengelolaan atas dana setoran awal BPIH yang terkumpul juga berdasarkan amanat UU No 34 tahun 2014 tentang Pengelolaan Keuangan Haji.

\section{KESIMPULAN}

Berdasarkan hasil penelitian di atas, dapat disimpulkan 2 (dua) macam kesimpulan, yaitu pertama, pada penyetoran dana awal BPIH calon jamaah haji melakukan transfer ke rekening Menteri Agama melalui BPS BPIH adalah menggunakan akad wadì'ah yad al dhamanah. Di mana calon jamaah haji sebagai pemilik dana menitipkan sejumlah uang kepada pihak Kementerian Agama, dan Kementerian Agama sebagai pihak penerima titipan.

Kedua, karena dalam penyetoran dana Awal BPIH menggunakan akad wadī'ah yad al dhamanah, maka jamaah haji tidak berhak atas hasil pengelolaan setoran awal BPIH. Namun bila pihak penerima titipan dalam hal ini Kementerian Agama ingin memberikan atau membagi hasil pengelolaan dana tersebut, maka diperbolehkan dengan bentuk sebagai imbalan kepada jamaah haji sebagai pemilik dana berupa bonus yang tidak disyaratkan sebelumnya.

\section{DAFTAR PUSTAKA}

Afif, Abdullah dan Masaji Antoro. Kumpulan Tanya Jawab Keagamaan Pustaka Ilmu Sunni Salafiyah-KTB. Yogyakarta: Ttp., 2015.

Ash-Sfiddieqy, Tengku Muhammad Hasbi. Pedoman Haji. Semarang: PT. Pustaka Rizki Putra, 1998.

Azam, Abdul Aziz Muhammad dan Abdul Wahhab Sayyed Hawwas, Fiqh Ibadah: Thaharah, Shalat, Zakat, Puasa, dan Haji. Jakarta: Amzah, 2013.

Azhara, Ayu dan Jelita. "Manajemen Dana Tabungan Haji Ditinjau Dari Perspsektif Ekonomi Islam Pada PT. Bank BNI Syariah dan PT Bank Syariah Mandiri Palangkaraya", Jurnal al-Qard, Vol. 4, No. 2 (Desember, 2017).

Bahar, Khalifi Elyas. Do'a dan Amalan agar Mendapat Panggilan Ziarah Haji dan Umrah. Yogyakarta: DIVA Press, 2013.

Bungi, Burhan. Analisa Data Penelitian Kualitatif, Pemahaman Filosofis dan Metodologis Kearah Penguasaan Modal Aplikasi. Jakarta: PT. Raja Grafindo Persada, 2003.

Dewi, Gemala, et.al. Hukum Perikatan Islam di Indonesia. Depok: Kencana, 2005.

Faniyah, Iyah. Kepastian Hukum Sukuk Negara Sebagai Instrumen Investasi di Indonesia. Yogyakarta: Deepublish, 2018.

Fatwa Dewan Syariah Nasional Nomor 101/DSN-MUI/X/2016 tentang Akad Al-Ijarah Al-Maushufah fi AlDzimmah.

Ghazaly, Abdul Rahman, et.al. Fiqh Muamalat. Jakarta: Kencana, 2012.

Harun. Fiqh Muamalah. Surakarta: Muhammadiyah University Press, 2017.

Hasbiyallah. Sudah Syar'ikah Muamalahmu? Panduan Memahami 
Seluk-Beluk Fiqh Muamalah.

Yogyakarta: Salma Idea, 2014.

https://edukasi.kompas.com/read/2017/08/0

1/18265581/mengenal-akad-wakalahdan-prinsip-dana-haji.

https://finance.detik.com/berita-ekonomibisnis/d-3898408/aturan-mainpengelolaan-dana-haji-terbit-bisadipakai-apa-saja/6.

https://jabar.kemenag.go.id/artikel-41836prosedur.

https://jabar.kemeneag.go.id/dberita506069-pendaftar-ibadah-haji-kotacirebon-membludak-kakankemenagperkenalkan-10-inovasipenyelenggaraan-haji.

https://kemenag.go.id/berita/info_grafis_rea $\mathrm{d} / 8 /$ tata-cara-dan-persyaratanpendaftaran-haji-reguler.

https://kemenag.go.id/berita/read/505045/su dah-akad-wakalah-pengelolaan-bpihtak-harus-izin-jemaah-lagi.

https://m.republika.co.id/berita/jurnalismewarga/wacana/17/07/31/otxeib396sulusi-atas-polemik-dan-haji diakses pada tanggal 8 Agustus 2018.

Huda, Nurul dan Mohamad Heykal, Lembaga Keuangan Islam Tinjauan Teorits dan Praktis. Jakarta: Kencana, 2010.

Izzati, Nurul. "Kontruksi Model Pengelolaan Keuangan Haji Pada Bank Syariah di Indonesia", Tesis. Yogyakarta: Fakultas Ilmu Ekonomi Islam Universitas Islam Negeri Sunan Kalijaga, 2015.

Mardani. Fiqh Ekonomi Syariah. Jakarta: Kencana, 2012.

Moleong, Lexy J. Metode Penelitian Kualititaif. Bandung: Remaja Rosda Karya, 2004.

Muslich, Ahmad Wardi. Fiqh Muamalat. Jakarta: Amzah, 2010.

Mustafa, Imam. Fiqih Mu'amalah Kontemporer. Jakarta: RajaGrafindo Persada, 2016.

Nawawi, Ismail. Fikih Muamalah Klasik dan Kontemporer Hukum Perjanjian,
Ekonomi, Bisnis, dan Sosial. Bogor: Ghalia Indonesia, 2012.

Putra, Dekky Aditya K. "Pelaksanaan Akad Tabungan Haji Pada Bank Riau Kepri Syari'ah Cabang Pekanbaru", Skripsi. Padang: Fakultas Hukum Universitas Andalas, 2011.

Rosyadi, Imron. Jaminan Kebendaan Berdasarkan Akad Syariah (Aspek Perikatan, Prosedur Pembebanan dan Eksekusi). Depok: Kencana, 2017.

Suhendi, Hendi. Fiqh Muamalah. Jakarta: RajaGrafindo, 2005.

Undang-Undang Republik Indonesia Nomor 13 Tahun 2008 tentang Peyelenggaraan Ibadah Haji.

Undang-Undang Republik Indonesia Nomor 34 Tahun 2014 tentang Pengelolaan Keuangan Haji.

Wiroso. Penghimpunan Dana dan Distribusi Hasil Usaha Bank Syariah. Jakarta: Grasindo, 2005.

www.infosyariah.com/2016/12/ijarahmaushufah-fi-al-zimmahimfz.html?m=1.

www.oxfordislamicstudies.com/article/opr/t 125/e925. 